\title{
Bibliocounseling To Enhance Resilience Of Bullying Victims Students At Junior High School In Nganjuk, East Java
}

\author{
Esty Rokhyani ${ }^{1}$, Sugiyo ${ }^{2}$, Samsudi $^{3}$, Edi Purwanto ${ }^{4}$

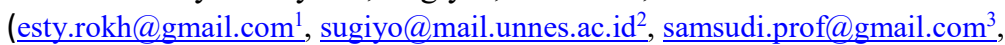 \\ edy.purwanto@gmail.unnes.ac.id ${ }^{4}$ ) \\ Doctoral Program Universitas Negeri Semarang, Indonesia ${ }^{1234}$
}

\begin{abstract}
Resilience plays an important role in life, because resilience is an essential factor for success and happiness. Resilience, which is a prevention program for children who are at risk of depression, can help them overcome the negative effects of family conflict and the low family cohesion that they experience everyday. The research is aimed at finding out the effectiveness of bibliocounseling to enhance resilience of Bullying Victims students at Junior High School in Nganjuk, East Java. The research conducted at Junior High School in Nganjuk, East Java involving 30 Yunior High school students used random sampling technique. Quantitative approach was applied in this research with latin square method. Data was collected by using 3 resilience scale (I have, I am, I can) used likert scale. Paired $\mathrm{T}$ test and one way anova was used too analyse the effectivity of intervention. The results of the study indicate that bibliocounseling techniques can increase resilience in students who are victims of bullying at Yunior High Schools in Nganjuk. The results indicated that reading book technique empirically has the highest score to enhance resilience of adolescence. The conclusion of study was bibliocounseling to enhance resilience of bullying victims students.
\end{abstract}

Keywords : bibliocounseling, resilience, student, bullying

\section{Introduction}

School institution that has an important role for the development of students. Junior high school are still said to be middle teens where their conditions tend to be unstable and really need to be guided well. Adolescents who are in search of identity will try various roles and ways of behaving. It is not uncommon for teenagers to act as they please and so adore their group identity and group acceptance of themselves, for example the occurrence of violent cases or so-called bullying. Bullying is categorized as a behavior that abuses its power to weak victims, individually or in groups and usually occurs repeatedly [1]. The occurrence of bullying between peers is getting stronger because of the factor of puberty and a normal identity crisis that occurs in adolescent development [2]. The reflection of the turmoil that occurs in students showed the violence they show out to others and others seems to be. Bullying can also be caused by revenge by the perpetrators because they were once neglected or have been victims of bullying. Rigby dan Johnson showed there are 25 schools in Australian give information many of cases Bullying which a negative im3acts for students [3]. 
Based on observations made by researchers on high school students in Nganjuk, there are still many people communicating among friends who use impolite sentences such as saying rude and like to encourage their friends to get along with others. Many students also violate regulations even though there are some students who obey the rules well. Based on the results of interviews conducted by researchers with 10 students from two junior high schools in Nganjuk, researchers found bullying cases. They stated that they had seen and become bullying perpetrators.

As for the bullying that occurs such as molesting victims who are considered weaker as a negative effects for students. The psychological pressure of students who are victims of bullying makes students not going to school, lazy to learn, and even threatened to drop out of school. This requires a student's ability to traumatic behaviour from the violent behaviour felt by students as they need a resilence. Pahlevi showed that there is a significant relationship between self-esteem with resilience have significant relationship, Social support with resilience having a relationship significant, religiosity with resilience has a significant relationship. [4]

Resilience is seen by experts as the ability to bounce back from traumatic situations or events [5] . Resilience is a person's ability to survive, rise, and adjust with difficult conditions so that individuals can be protected from the negative effects of risk and misfortune or pressure. Measurement resilience uses seven aspects, respectively consists of from aspect emotion regulation, aspects control of impulses, aspects of optimism, aspects of causal analysis, aspects of empathy, aspects self-efficacy, and aspects of reaching out [6]. Resilience is the ability of individuals to adapt and adapt to changes, demands, and disappointments that arise in life [7]. The basic assumption in the study of resilience is that some individuals remain fine even though they have experienced a situation full of adversity and are at risk, while some other individuals fail to adapt and fall into adversity or even more severe risks [8] Karacan shows that bibliocounseling is effective in increasing the resilience of middle school students[9]. Moore and Woodcock found that resilience overcame students who were victims of bullying [10]. Hoffman dan Hancock, also state that children who are resilient are able to manipulate and shape their environment, face the pressure of living well, quickly adapt to new situations, are more tolerant in the face of frustration and anxiety [11].

The aim to be achieved through this research is to analyze the effectiveness of bibliocounseling in increasing the resilience of students who are victims of bullying and to know the difference in the effect of each bibliocounseling technique on aspects of resilience of students who are victims of bullying at Yunior High Schools in Nganjuk. This research can provide benefits for various parties, including students, guidance and counseling teachers and researchers. This study will bridge the disclosure of various developmental problems experienced by students in view of bibliocounseling. For guidance and counseling teachers or school counselors can use the results of studies to add knowledge and skills related to various theories and approaches in counseling. For further researchers, this research can be used as a reference for resilience and bibliocounseling as one of the techniques for increasing the resilience of students who are victims of bullying. 


\section{Methods}

This study used a quantitative approach. The method used the experimental method using the Latin-Square design within-subject type. This design was chosen to ensure that the treatment to increase the resilience of students of bullying victims at Yunior High Schools in Nganjuk was presented in a balanced manner with the same frequency.

Table 1. Research Schema with Latin Square Design

\begin{tabular}{|c|c|c|c|}
\hline \multirow{2}{*}{ Group } & \multicolumn{3}{|c|}{ Aspects } \\
\hline & I $H A V E$ & $I A M$ & $I C A N$ \\
\hline A & $\begin{array}{l}\text { Book } \\
\text { reading }\end{array}$ & $\begin{array}{l}\text { Story } \\
\text { telling }\end{array}$ & $\begin{array}{c}\text { Movies } \\
\text { Watching }\end{array}$ \\
\hline B & $\begin{array}{c}\text { Movies } \\
\text { Watching }\end{array}$ & $\begin{array}{c}\text { Book } \\
\text { reading }\end{array}$ & Story telling \\
\hline $\mathrm{C}$ & $\begin{array}{l}\text { Story } \\
\text { telling }\end{array}$ & $\begin{array}{c}\text { Movies } \\
\text { Watchin } \\
\mathrm{g}\end{array}$ & $\begin{array}{l}\text { Book } \\
\text { reading }\end{array}$ \\
\hline
\end{tabular}

The research was conducted at Yunior High Schools in Nganjuk, East Java. involving student victims of bullying as the subject of research and given bibliocounseling intervention namely reading books, listening to stories and watching movies. The sampling technique in this study uses random sampling, which is a sample selection strategy that provides an opportunity for all students of bullying victims at Yunior High Schools in Nganjuk, East Java to become a sample [12]. The number of samples is 21 people. This study has two variables, namely 1) Independent variables, namely bibliocounseling techniques. 2) the dependent variable, namely the resilience of students who are victims of bullying.

Adolescent resilience is measured by I have, which is a resilience forming factor that describes external support in increasing resilience, b) I am, namely the strength that comes from within the individual and c) I can, namely the ability possessed by students. The counseling referred to in this study is a series of activities to provide assistance from counselors or researchers to students who are victims of bullying at Yunior High Schools in Nganjuk. Assistance provided involves 3 bibliocounseling techniques, namely reading books, listening to stories, and watching films given in group settings. The research instrument used a Likert scale with a choice of answers from Strongly Agree (SS), Agree (S), Disagree (TS), and Strongly Disagree (STS) with the weight values in sequence, $5,4,3,2,1$.

The analysis technique used to determine the effectiveness of each intervention session is the effectiveness of certain techniques on certain aspects of resilience, then paired t-test is used. To find out the differences in the influence of each technique on aspects of resilience, one way ANOVA statistical analysis was used, and to find out how much influence each technique had on aspects of resilience, a post hoc test was used. 


\section{Results and Discussion}

\subsection{Effectiveness of Bibliocounseling in Increasing Students Resilience of Bullying Victims at Yunior High Schools in Nganjuk}

Test Results for effectiveness of bibliocounseling in increasing the resilience of students who are victims of bullying at Yunior High Schools in Nganjuk is tested through paired t-test. The effectiveness test was carried out in order to compare the pre-test and post-test scores of the research subjects, assuming the data were normally distributed.

Table 2. Paired t-Test Result

\begin{tabular}{cccrrl}
\hline Session & Mean & STDEV & t count & \multicolumn{1}{l}{ Sig. } & Keterangan \\
\hline $\mathbf{1}$ & 15,00 & 3,91 & 10,135 & 0,000 & Effective \\
$\mathbf{2}$ & 18,86 & 4,14 & 12,050 & 0,000 & Effective \\
$\mathbf{3}$ & 29,14 & 8,87 & 8,685 & 0,000 & Effective \\
$\mathbf{4}$ & 8,714 & 5,41 & 4,264 & 0,005 & Effective \\
$\mathbf{5}$ & 18,43 & 4,65 & 10,486 & 0,000 & Effective \\
$\mathbf{6}$ & 24,71 & 6,87 & 9,514 & 0,000 & Effective \\
$\mathbf{7}$ & 0,43 & 0,97 & 1,162 & 0,289 & Not Effective \\
$\mathbf{8}$ & 6,71 & 2,06 & 8,629 & 0,000 & Effective \\
$\mathbf{9}$ & 34,14 & 13,04 & 6,925 & 0,000 & Effective \\
\hline
\end{tabular}

The results of testing the effectiveness of bibliocounseling to increase the resilience of students who are victims of bullying at Yunior High Schools in Nganjuk are based on calculations of $t$ count and t table. Based on the results of the testing, it was shown that the effectiveness of bibliocounseling on the resilience of students who were victims of bullying at Yunior High Schools in Nganjuk in three sessions of treatment showed significant results except the session session listened to the stories on aspects of I have. The effectiveness of bibliocounseling to increase the resilience of students who are victims of victims of bullying at Yunior High Schools in Nganjuk means that there was a difference in the tendency of resilience before the bibliocounseling and after bibliocounseling treatments. The test results mean that the treatment was effective, in the sense that the treatment is able to increase the tendency of resilience of students who are victims of bullying at Yunior High Schools in Nganjuk.

\subsection{Differences in the Effect of Bibliocounseling Techniques on Resilience}

The difference in the influence of each bibliocounseling technique on aspects of resilience of students who are victims of bullying at Yunior High Schools in Nganjuk used one way ANOVA analysis. This analysis is used considering that this study has 3 variables (multivariable) with 3 types of treatment and 3 groups with the latin square method. One way ANOVA analysis was performed to determine the existence of certain technical differences in aspects of resilience and to know how much the difference was. In connection with the technique used there are 3 types with aspects that are intervened as well as 3 types, so to balance the frequency of use of techniques in each skill a technique is repeated in different groups. 
Table 3. One Way Anova Test Results

\begin{tabular}{lccc}
\hline \multicolumn{1}{c}{ Technique } & F count & $\begin{array}{c}\text { F } \\
\text { table }\end{array}$ & Sig \\
\hline $\begin{array}{l}\text { Movies } \\
\text { watching }\end{array}$ & 28,813 & 4,28 & 0,000 \\
Story Telling & 51,628 & 4,28 & 0,000 \\
Book reading & 10,565 & 4,28 & 0,010 \\
\hline
\end{tabular}

Based on table Table 3 where $\mathrm{F}$ arithmetic $(28,813)$ is greater than $\mathrm{F}$ table $(4.28)$, and significant or probability $(0,000)<$ than 0.05 then $\mathrm{Ho}$ is rejected, in other words there is an average difference between aspects of I have, I am and I can by using a movie watching technique. $\mathrm{F}$ arithmetic $(51,628)$ is greater than $\mathrm{F}$ table $(4.28)$, and significant or probability $(0,000)<$ than 0.05 then Ho is rejected, in other words there is an average difference between aspects of I have, Iam and I can use Story Telling techniques. F count (10.565) is greater than F table (4.28), and significant or probability $(0.01)<$ than 0.05 then Ho is rejected, in other words there is an average difference between aspects I have, I am and I can by using a book reading technique.

Based on one way ANOVA analysis on the technique of reading books on aspects of I have, I am, and I can, it was found that I can be the most significant aspect increased followed by aspects of I am and aspects I have. The technique of reading books has a different impact on each aspect. In other words, reading techniques have the highest impact on students' resilience.

The results of this study are in accordance with the opinion of Resnick et.al which explains that I Solve to help students improve their abilities in problem solving or the ability to solve problems from books [13]. I Solve are the steps that the teacher and counselor must do in guiding their students to master the ability to solve problems through books. The I Solve approach in reading books has succeeded in increasing students' ability to solve problems, because reading a book using the I Solve method can help students discuss the problem freely and release emotional and mental stress. The reading technique, students who are victims of bullying at Yunior High Schools in Nganjuk understand that they are not alone in facing problems. In the counseling session, students of the Nganjuk high school bullying victims develop insight or understanding of the problems experienced by the characters in the story, identify the various root causes that arise and identify the various possible impacts that will arise from the problem. In connection with the effectiveness of book reading in controlling emotions, Pehrsson and McMillen state that the benefits of bibliocounseling through reading books include being able to reduce negative emotions and replace them with more positive behaviors and feelings[14]. Reading books is effective in improving problem solving skills, increasing feelings of emotion, developing empathy, and increasing self-awareness.

Based on one way ANOVA analysis on the technique of watching movies on aspects of I have, I am, and I can, it was found that I can be the most significant aspect increased followed by aspects I have and I am. The technique of watching movies has a different impact on each aspect. In other words, the technique of watching films has the highest impact on students' interpersonal and intrapersonal communication skills, ability to solve problems, problemsolving abilities, ability to manage emotions themselves, the ability to know emotions about themselves and others, and the ability to make trusted relationships. A comprehension because it involves audio, visuals, with a clearer description of the storyline. Film can act as a therapeutic experience because it can provide a metaphor that can provide new insights or views for the 
audience. By looking at films and discussing stories in films, struggles of characters or characters, and moral dilemmas presented in films, counselees can assess content metaphor that is meaningful to counselees [15]. Some students who are victims of Yunior High Schools in Nganjuk are experiencing violence so they need to communicate sensitive issues that they face with adults.

Based on one way anova analysis on the technique of listening to stories on aspects of I have, I am, and I can, it was found that I am the most significant aspect increased followed by aspects I can and I have. The technique of listening to stories gives a different impact for each aspect. In other words, the technique of listening to stories provides the highest impact on students' interpersonal and intrapersonal communication skills, ability to solve problems, problem solving abilities, ability to manage emotions, ability to know emotions of themselves and others, and the ability to make trusted relationships.

When analyzed on each bibliocounseling technique both on reading, watching movies, and listening to stories, aspects of I can are consistently significant aspects in all three aspects. In this study, reading a book was the most significant technique in increasing the resilience of students who were victims of Nganjuk Public Middle School bullying based on the average of each treatment on aspects of resilience. This is caused by several factors, including when reading books, students who are victims of bullying at Yunior High Schools in Nganjuk are able to actively engage cognitively in digesting the stories in the book. Active cognitive involvement in the story will not only improve the cognitive understanding function of students of Yunior High Schools in Nganjuk bullying victims, but also will increase cognitive flexibility in developing various alternative solutions to problems other than those displayed in the book. This is different from watching and listening to stories where students who are victims of bullying at Yunior High Schools in Nganjuk are more passive because the film has provided the full audio, visual and character needed by the audience. Students by reading books, individuals can actively imagine the stories presented compared to films and stories, where all the elements of the story have been presented.

\section{Conclusion}

Based on the results of the study, the technique of reading books is better in improving the three aspects of resilience followed by the technique of watching movies and listening to stories. The aspect of resilience aspect I can be with indicators of interpersonal and intrapersonal communication skills, problem solving abilities, ability to manage feelings and stimuli, the ability to know emotions of oneself and others, the ability to establish trustworthy relationships, followed by aspects of I am indicators of feeling loved, loving, altruistic, having pride in oneself, having hope and responsibility, having trust, hope and confidence, and finally the aspect I have with indicators of having a trusted relationship, having a role model, having an urge to be an independent individual so students of bulliying victims are able to overcome problems if they are treated or bullied by other students. 


\section{References}

[1] S.E. Moore, E.N. Rosana and G.S. James. Consequences of Bullying Victimization in Childhood and Adolescence: A systematic Review and Meta Analysis.World Journal of Psychiatry. 482. 209-212. 2015.

[2] K. Rigby, School Perspective on Bullying and Prevenative Strategies: An Exploratory Study. Australian Journal of Education. 144. Hal.441-455. 2017.

[3] K. Rigby and K. Johnson. The Prevalence and Efectiveness of anti Bullying Strategies Employed in Australiaan Schools. University of South Australia. 2016.

[4] R. Pahlevi. D. Y. P. Sugiharto dan M. Jafar. Prediksi Self-Esteem, Social Support dan Religiusitas terhadap Resiliensi. Jurnal Bimbingan Konseling. Vol.6 (10). 2017.

[5] F.J Infurna and S.S. Luthar. The Multidimensial Nature of Resilience to Spousal Loss. Journal of Personality and Social Psichology Avance Online Publication. 227. 151-167. 2016.

[6] M.A. Suryaman, S. Stanislaus dan M.I.Mabrur. 2014. Pengaruh Religiusitas Terhadap Resiliensi Pada Pasien Rehabilitasi Narkoba Yayasan Rumah Damai Semarang. Intuisi Jurnal Ilmiah Psikologi (6).2014. Avaiable. http://journal.unnes.ac.id/nju/index.php/INTUISI

[7] D. Woods and M. Branlat. Resilience Engineering in Parctice. 555. The Journal of Human Factors and Ergonomics Society. Hal. 127-144. 2011.

[8] R. R Hoffman and P.A Hancock. Measuring Resilience. The Journal of Human Factors and Ergonomics Society. 304. 112-119. 2017.

[9] N. Karacan. The Efffect Of Self-Esteem Enrichment Bibliocounseling Program on The SelfEsteem Level of Sixth Grade Students. Thesis. Middle East University: Not Published. 2009.

[10] B. Moore and S. Woodcock. Resilience to Bullying: towards an alternative to the anti-Bullying approach. Educational Psychology in Practice, 331, 65-80. 2017. Avaiable . https://doi.org/10.1080/02667363.2016.1233488

[11] R. R Hoffman and P.A Hancock. Measuring Resilience. The Journal of Human Factors and Ergonomics Society. 304. 112-119. 2017

[12] J. Creswell. Educational Research, Planning, Conducting and Evaluating Quantitative and Qualitatif Research. New York: Pearson Education. 2012

[13] B. Resnick, P. Gwyther, and A. Roberto. Resilience In Aging : Concepts, Research, and Outcomes. New York :Springer. 2011.

[14] D.E. Pehrsson, and P. McMillen. Bibliotherapy: Overview and implications for counselors ACAPCD-02. Alexandria, VA: American Counseling Association. 2009.

[15] Z.A. Wu. Applyng Cinematherapy with Adolescent. Disertations of Universitas California: not publications. 2008. 